\title{
PHOSPHATE FERTILIZATION CAN INCREASE YIELD OF PRODUCTIVE GRASS PEA (Lathyrus sativus L.) CROPS IN P-RETENTIVE SOILS
}

\author{
Adolfo Montenegro ${ }^{1^{*}}$, and Mario Mera ${ }^{1}$
}

\begin{abstract}
The effect of P fertilization on grass pea (Lathyrus sativus L.) yield and yield components was evaluated on soils with low P availability and high P retention capacity in small-scale farms of the Araucanía Region in southern Chile. Trials were conducted during 2000-2001, 2001-2002, and 2002-2003, in six sites; three sites in Lumaco and three in the Selva Oscura area. Six rates of $\mathrm{P}\left(0,21.8,43.6,65.4,87.2\right.$, and $\left.109.0 \mathrm{~kg} \mathrm{ha}^{-1}\right)$ were evaluated in a randomized complete block design with four replicates. Grass pea cv. Luanco-INIA was sown at 47 seeds $\mathrm{m}^{-2}$. Mean grain yield for all trials was $2456 \mathrm{~kg} \mathrm{ha}^{-1}$. Phosphate fertilization increased grass pea grain yield in both areas during 2000 and 2001. There was no significant effect in 2002. The 2002 cropping season had an unusually high spring-summer rainfall, which may have enhanced the P mineralization rate from organic soil fraction, and thus $\mathrm{P}$ availability. According to this study, grass pea crops in soils with $<10 \mathrm{mg} \mathrm{kg}^{-1}$ of available P-Olsen should respond to $\mathrm{P}$ fertilization.
\end{abstract}

Key words: grass pea, Lathyrus, phosphorus, neglected crops, cool-season legumes.

\section{INTRODUCTION}

Grass pea is a grain legume crop used for human and animal consumption since ancient times (Hanbury et al., 2000). The presence of $\beta$-N-oxalyl-L- $\alpha, \beta-$ diaminopropionic acid ( $\beta$-ODAP) in grass pea seeds is thought to increase vulnerability to neurolathyrism, a neurodegenerative disease (Lambein et al., 2007). As a result, lowODAP lines (Campbell et al., 1994) and cultivars (Siddique et al., 2006) have been found that may enhance interest in this protein crop. The potential of grass pea for animal feed also depends on the achievement of yields that make it competitive with other protein-rich ingredients.

Grass pea is grown on a wide range of soils, including those with low fertility and poor structure (Siddique et al., 1996). In southern Chile, grass pea is cultivated by small farmers with limited resources, on typically eroded soils as a result of poor management. The Araucanía Region $\left(37^{\circ} 30^{\prime}-39^{\circ} 30^{\prime} \mathrm{S}\right)$ has a particularly high number of such small farmers and its soils are characterized by low levels of available P-Olsen (Montenegro, 1991) though relatively high grain yields are often achieved. Hence, $\mathrm{P}$ fertilization is a determining factor in the yield of most crops.

Information on grass pea response to $\mathrm{P}$ fertilization is very scarce. Its effect on grain yield and yield

${ }^{1}$ Instituto de Investigaciones Agropecuarias, Centro Regional de Investigación Carillanca, Casilla 58-D, Temuco, Chile. *Corresponding author (amontene@inia.cl).

Received: 11 January 2008.

Accepted: 06 June 2008. components is largely unknown, particularly in soils with high $\mathrm{P}$ retention capacity. The comprehensive review by Campbell (1997) does not refer to P fertilization, but emphasizes that grass pea is considered a hardy crop requiring low or zero inputs. However, Sarkar et al. (2003) found that applying P increased grass pea grain yield grown in an Entisol of India with $\mathrm{pH} 7.5$, $0.53 \%$ organic carbon, and $26 \mathrm{~kg} \mathrm{ha}^{-1}$ of $\mathrm{P}_{2} \mathrm{O}_{5}$. In Chile, a clear effect of up to $65.4 \mathrm{~kg} \mathrm{ha}^{-1} \mathrm{P}$ on grass pea grain yield was reported by Ellena (1983) in an Andisol of Valdivia. Later, Montenegro et al. (2001) explained in a preliminary report that $\mathrm{P}$ fertilization was associated to higher grass pea yields in Araucanía soils with high P retention capacity. Krarup (2002) did not find any grass pea response to $\mathrm{P}$ fertilization in a soil of the Valdivia series belonging to the medial, mesic of the Duric Hapludands family (CIREN, 2003) with P-Olsen availability of $12 \mathrm{mg} \mathrm{kg}^{-1}$ or greater.

Araucanía Region soils have high levels of $\mathrm{P}$ retention, generally above $70 \%$ (Sadzawka et al., 1999) reaching levels as high as $95 \%$ in areas such as Victoria. Phosphorus retention of $70-99 \%$ has been reported for the A soil horizon in Andisols of southern Chile (Pino et al., 1998; Besoaín and Sadzawka, 1999). A wide range of farmers was surveyed in the Araucanía Region indicating that $90 \%$ of soils have available P-Olsen $<15 \mathrm{mg} \mathrm{kg}^{-1}$ (Sadzawka et al., 1999). Moreover, 60\% of such soils have P-Olsen $<10 \mathrm{mg} \mathrm{kg}^{-1}$ which is considered a critical level for most crops. This level is frequent in small farms, with a mean of $7.5 \mathrm{mg} \mathrm{kg}^{-1}$ for grass pea producers in 
Lumaco (A. Montenegro, unpublished data, 2000), one of the areas of the Araucanía Region where the reported experiments were conducted.

Phosphorus is generally absorbed by crop plants to a moderate extent compared to other macronutrients. However, in P-retentive soils such as those in southern Chile, $\mathrm{P}$ fertilizers should be applied at high rates, for example, up to $87 \mathrm{~kg} \mathrm{ha}^{-1} \mathrm{P}$ for wheat (Montenegro et al., 1999a) and oilseed rape (Montenegro et al., 1999b).They should be localized in the furrow to increase efficiency. Consequently, it is important to gather information on the magnitude of yield response of grass pea to $P$ fertilization in soils where its availability is limited.

\section{MATERIALS AND METHODS}

The study was conducted under dryland conditions during three cropping seasons (2000-2001, 2001-2002, and 2002-2003 referred hereafter as 2000, 2001, and 2002) in

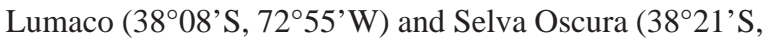
$72^{\circ} 11^{\prime} \mathrm{W}$ ), Araucanía Region, located about $150 \mathrm{~km}$ NW and $60 \mathrm{~km} \mathrm{NE}$ of Temuco, respectively. Experiments in Lumaco were conducted on a silty clay loam Inceptisols, Lumaco Series, belonging to the fine, mixed, termic, mesic of the Fluventic Dystrudepts family (CIREN, 2002). Experiments in Selva Oscura were conducted on a silty clay loam Andisols, Victoria Series, belonging to the medial, mesic of the Typic Durudands family (CIREN, 2002). Methodology for chemical determination was in accordance with Sadzawka et al. (2006). Specific sites within Lumaco and Selva Oscura were different each year.

The chemical characterization of soils $(0-20 \mathrm{~cm}$ depth) is shown in Table 1. Available P-Olsen in Lumaco soils was low in all seasons. In Selva Oscura, available P-Olsen was considered low to medium in 2000, and low in 2001 as well as 2002. Traditional crops, like wheat (Triticum aestivum L.) and oilseed rape (Brassica napus L.), for which more agronomic information is available, are expected to clearly respond to $\mathrm{P}$ fertilization in soils at these P-Olsen levels. In Lumaco, exchangeable $\mathrm{K}$ was low in 2000 and 2002, medium in 2001, and extractable S was low, whereas Al saturation was low in 2000 and 2001, but high in 2002. In Selva Oscura, soils had relatively high exchangeable $\mathrm{K}$, low extractable $\mathrm{S}$, and medium to high Al saturation.

Luanco-INIA, a large-seeded grass pea cultivar (Mera et al., 2003), was sown at 47 seeds $\mathrm{m}^{-2}$. Seeds were treated with carboxin + thiram, fipronil, and inoculated just prior to sowing with a cocktail of Rhizobium strains isolated from grass pea nodules provided by the Universidad de Concepción, Chillán, Chile. Sowing dates in Lumaco were 17 May 2000, 16 May 2001, and 7 May 2002. Sowing dates in Selva Oscura were 11 August 2000, 7 August 2001, and 3 September 2002. A randomized complete block design was used with four replicates, except in Lumaco in 2000 and 2001 where only three replicates were carried out. Plots had six rows, $4 \mathrm{~m}$ long and spaced

Table 1. Chemical characterization of soils (0-20 cm depth) from three different sites in two areas of southern Chile where experiments of $\mathbf{P}$ fertilization in grass pea were conducted during 3 years.

\begin{tabular}{|c|c|c|c|c|c|c|}
\hline \multirow{2}{*}{$\begin{array}{l}\text { Chemical parameters } \\
\text { and its unit }\end{array}$} & \multicolumn{3}{|c|}{ Lumaco } & \multicolumn{3}{|c|}{ Selva Oscura } \\
\hline & 2000 & 2001 & 2002 & 2000 & 2001 & 2002 \\
\hline P-Olsen , mg kg-1 & 9 & 5 & 5 & 11 & 6 & 4 \\
\hline Organic C, \% & 2.9 & 2.3 & 3.5 & 7.0 & 6.4 & 4.1 \\
\hline pH (water) & 5.8 & 5.8 & 5.2 & 5.5 & 5.8 & 5.6 \\
\hline Exchangeable Ca, $\mathrm{cmol} \mathrm{kg}^{-1}$ & 4.9 & 3.35 & 1.97 & 4.9 & 5.18 & 9.05 \\
\hline Exchangeable Mg, cmol kg-1 & 1.04 & 1.3 & 0.76 & 1.45 & 0.8 & 2.16 \\
\hline Exchangeable $\mathrm{Na}, \mathrm{cmol} \mathrm{kg}^{-1}$ & 0.26 & 0.08 & 0.15 & 0.11 & 0.07 & 0.13 \\
\hline Exchangeable $\mathrm{K}, \mathrm{cmol} \mathrm{kg}^{-1}$ & 0.07 & 0.52 & 0.13 & 0.88 & 0.96 & 0.38 \\
\hline Sum of bases, $\mathrm{cmol} \mathrm{kg}^{-1}$ & 6.3 & 5.25 & 3.01 & 7.38 & 7.01 & 11.72 \\
\hline Exchangeable $\mathrm{Al}, \mathrm{cmol} \mathrm{kg}^{-1}$ & 0.09 & 0.07 & 1.24 & 0.79 & 0.28 & 1.2 \\
\hline Effective CEC, $\mathrm{cmol} \mathrm{kg}^{-1}$ & 6.4 & 5.32 & 4.25 & 8.17 & 7.29 & 12.92 \\
\hline Al saturation, \% & 1.4 & 1.3 & 29.2 & 9.7 & 3.8 & 9.3 \\
\hline Extractable S, mg kg-1 & 2.4 & 6.5 & - & 4.5 & 1.3 & - \\
\hline Available $\mathrm{Zn}, \mathrm{mg} \mathrm{kg}^{-1}$ & 0.3 & 0.1 & - & 1.5 & 0.1 & - \\
\hline Available B, mg kg-1 & 0.4 & 0.2 & - & 0.5 & 0.2 & - \\
\hline Available Cu, mg kg-1 & 3 & 1.4 & & 2.5 & 0.6 & - \\
\hline
\end{tabular}


$35 \mathrm{~cm}$ apart. Treatments were 0, 21.8, 43.6, 65.4, 87.2, and $109.0 \mathrm{~kg} \mathrm{ha}^{-1} \mathrm{P}$, as banded superphosphate below the seed $\left(46 \% \mathrm{P}_{2} \mathrm{O}_{5}\right)$. Base fertilization was $83 \mathrm{~kg} \mathrm{ha}^{-1} \mathrm{~K}$ and $36 \mathrm{~kg} \mathrm{ha}^{-1} \mathrm{~S}$ as broadcast $\mathrm{K}_{2} \mathrm{SO}_{4}$ in all experiments and for all $\mathrm{P}$ treatments. In 2002, Al soil saturation recommended a liming treatment, so 3.5 and $3.0 \mathrm{t} \mathrm{ha}^{-1} \mathrm{CaCO}_{3}$ with an agronomic value of $92.44 \%$ was applied in Lumaco and Selva Oscura, respectively.

Aboveground biomass samples were taken in Lumaco during grass pea flowering to estimate nutrient contents only in year 2000. Grain was harvested 17 January 2001, 2 January 2002, and 16 January 2003 in Lumaco, and 26 January 2001, 21 January 2002, and 25 February 2003 in Selva Oscura. Nutrient content in biomass and grain was estimated at both locations only in 2000. Nitrogen content in biomass and grain was determined by digestion with sulphuric acid and Kjeldahl. Phosphorus content in aboveground biomass and grain was determined by calcination, digestion with $\mathrm{HCl}$, and colorimetry by vanadate. Potassium, $\mathrm{Ca}, \mathrm{Mg}$, $\mathrm{Zn}$, and $\mathrm{Cu}$ in aboveground biomass and grain were determined by calcination, digestion with $\mathrm{HCl}$, atomic absorption, and emission spectrophotometry. Boron in the aboveground biomass and the grain was determined by calcination, digestion with $\mathrm{HCl}$, and colorimetry with azomethine-H (Sadzawka et al., 2007). Samples of aboveground biomass were taken in Lumaco and Selva Oscura in 2001 during flowering in order to estimate aboveground dry biomass per hectare. Grain yield was estimated using $3.5 \mathrm{~m}$ of the four central rows at $14 \%$ moisture. Yield components were estimated from a row random sample of $25 \mathrm{~cm}$. Nutrient content of grains from both areas was determined in 2000. Analysis of variance and regression were performed with SAS (SAS Institute, 1992).

\section{RESULTS AND DISCUSSION}

In 2000 and 2001, P fertilization increased grain yields in both areas, in agreement with previous findings (Ellena, 1983). However, no significant effect was found at any site in 2002 (Tables 2 and 3).

Grain yield mean was considerably higher in Lumaco (2908 kg ha' ${ }^{-1}$ ) than Selva Oscura (1268 kg ha-1) in 2000. The higher level of Al saturation in Selva Oscura (Table 1) may have been detrimental to grain yield. Furthermore, soil structure in Selva Oscura was altered by extremely high rainfall in June 2000 (Figure 1), and a superficial soil crust resulted from the impact of raindrops (Casanova et al., 2006), probably affecting root development. In 2000, the effect of increasing $\mathrm{P}$ fertilization rates on grain yield fitted a quadratic model response with Equation [1] for Lumaco and Equation [2] for Selva Oscura:

$y=2335.39+18.2995 \mathrm{P}-0.097557 \mathrm{P}^{2}$, with $\mathrm{R}^{2}=0.60$

$y=875.14+8.300078 \mathrm{P}-0.01356 \mathrm{P}^{2}$, with $\mathrm{R}^{2}=0.77$

where $y$ is the grain yield $\left(\mathrm{kg} \mathrm{ha}^{-1}\right), \mathrm{P}$ is the amount of $\mathrm{P}$ applied $\left(\mathrm{kg} \mathrm{Pha}^{-1}\right)$, and $\mathrm{R}^{2}$ is the coefficient of determination for the equation.

Contrary to 2000, there were higher mean yields in 2001 in Selva Oscura (2465 kg ha-1) than in Lumaco $\left(1687 \mathrm{~kg} \mathrm{ha}^{-1}\right)$. Water availability in 2001 was less than

Table 2. Effect of $\mathbf{P}$ fertilization on stand, grain yield, and grain weight of grass pea cv. Luanco-INIA in Lumaco, southern Chile, during 3 years.

\begin{tabular}{|c|c|c|c|c|c|c|c|c|c|}
\hline \multirow[b]{2}{*}{$\begin{array}{l}\text { Applied } \\
\text { phosphorus }\end{array}$} & \multicolumn{3}{|c|}{2000} & \multicolumn{3}{|c|}{2001} & \multicolumn{3}{|c|}{2002} \\
\hline & $\begin{array}{l}\text { Stand } \\
\text { plants }\end{array}$ & $\begin{array}{c}\text { Grain } \\
\text { yield }\end{array}$ & $\begin{array}{l}\text { Grain } \\
\text { weight }\end{array}$ & $\begin{array}{l}\text { Stand } \\
\text { plants }\end{array}$ & $\begin{array}{l}\text { Grain } \\
\text { yield }\end{array}$ & $\begin{array}{c}\text { Grain } \\
\text { weight }\end{array}$ & $\begin{array}{l}\text { Stand } \\
\text { plants }\end{array}$ & $\begin{array}{l}\text { Grain } \\
\text { yield }\end{array}$ & $\begin{array}{c}\text { Grain } \\
\text { weight }\end{array}$ \\
\hline $\mathrm{kg} \mathrm{ha}^{-1} \mathrm{P}$ & plant $\mathrm{m}^{-2}$ & $\mathrm{~kg} \mathrm{ha}^{-1}$ & $\mathrm{mg}$ & plant $\mathrm{m}^{-2}$ & $\mathrm{~kg} \mathrm{ha}^{-1}$ & $\mathrm{mg}$ & plant $\mathrm{m}^{-2}$ & $\mathrm{~kg} \mathrm{ha}^{-1}$ & $\mathrm{mg}$ \\
\hline 0.0 & 41.4 & 2359 & 327 & 32.8 & 1036 & 286 & 40.2 & 3248 & 285 \\
\hline 21.8 & 40.6 & 2695 & 333 & 33.1 & 1553 & 284 & 38.2 & 3126 & 305 \\
\hline 43.6 & 40.8 & 2841 & 340 & 29.2 & 1553 & 279 & 38.6 & 3598 & 288 \\
\hline 65.4 & 39.7 & 3155 & 341 & 32.0 & 1700 & 281 & 40.8 & 3482 & 283 \\
\hline 87.2 & 38.8 & 3282 & 346 & 30.4 & 1945 & 294 & 38.6 & 3425 & 297 \\
\hline 109.0 & 39.5 & 3114 & 330 & 35.0 & 2334 & 296 & 34.5 & 3014 & 292 \\
\hline Mean & 40.1 & 2908 & 336 & 32.1 & 1687 & 287 & 38.5 & 3316 & 292 \\
\hline $\mathrm{CV}, \%$ & 4.7 & 7.8 & 2.7 & 12.3 & 16.4 & 6.3 & 12.40 & 14.0 & 6.1 \\
\hline F & 0.79 & 6.91 & 2.04 & 1.10 & 9.83 & 0.59 & 0.86 & 0.93 & 0.88 \\
\hline$P>F$ & ns & 0.01 & ns & ns & $<0.01$ & ns & ns & ns & ns \\
\hline
\end{tabular}

Grain weight is a mean value calculated from a random sample of 500 grains. ns = non significant.

$\mathrm{CV}$ : coefficient of variation. F: ratio of treatments mean square and experimental error mean square. 
Table 3. Effect of $\mathbf{P}$ fertilization on stand, grain yield, and grain weight of grass pea cv. Luanco-INIA in Selva Oscura, southern Chile, during 3 years.

\begin{tabular}{|c|c|c|c|c|c|c|c|c|c|}
\hline \multirow[b]{2}{*}{$\begin{array}{l}\text { Applied } \\
\text { phosphorus }\end{array}$} & \multicolumn{3}{|c|}{2000} & \multicolumn{3}{|c|}{2001} & \multicolumn{3}{|c|}{2002} \\
\hline & $\begin{array}{l}\text { Stand } \\
\text { plants }\end{array}$ & $\begin{array}{l}\text { Grain } \\
\text { yield }\end{array}$ & $\begin{array}{c}\text { grain } \\
\text { weight }\end{array}$ & $\begin{array}{l}\text { Stand } \\
\text { plants }\end{array}$ & $\begin{array}{l}\text { Grain } \\
\text { yield }\end{array}$ & $\begin{array}{l}\text { grain } \\
\text { weight }\end{array}$ & $\begin{array}{l}\text { Stand } \\
\text { plants }\end{array}$ & $\begin{array}{l}\text { Grain } \\
\text { yield }\end{array}$ & $\begin{array}{c}\text { grain } \\
\text { weight }\end{array}$ \\
\hline $\mathrm{kg} \mathrm{ha}^{-1} \mathrm{P}$ & plant $\mathrm{m}^{-2}$ & $\mathrm{~kg} \mathrm{ha}^{-1}$ & $\mathrm{mg}$ & plant $\mathrm{m}^{-2}$ & $\mathrm{~kg} \mathrm{ha}^{-1}$ & $\mathrm{mg}$ & plant $\mathrm{m}^{-2}$ & $\mathrm{~kg} \mathrm{ha}^{-1}$ & mg \\
\hline 0.0 & 38.9 & 870 & 354 & 44.1 & 2143 & 298 & 45.7 & 2796 & 368 \\
\hline 21.8 & 40.9 & 1065 & 365 & 39.2 & 2126 & 292 & 45.6 & 2952 & 357 \\
\hline 43.6 & 37.7 & 1203 & 370 & 44.9 & 2386 & 297 & 42.3 & 3490 & 353 \\
\hline 65.4 & 35.5 & 1342 & 365 & 35.9 & 2535 & 309 & 40.7 & 2833 & 359 \\
\hline 87.2 & 38.2 & 1521 & 356 & 45.3 & 2966 & 299 & 43.6 & 3070 & 369 \\
\hline 109.0 & 39.8 & 1610 & 370 & 43.6 & 2634 & 307 & 45.7 & 3584 & 371 \\
\hline Mean & 38.5 & 1268 & 363 & 42.2 & 2465 & 300 & 43.9 & 3095 & 363 \\
\hline CV, \% & 5.1 & 11.9 & 2.8 & 11.0 & 9.0 & 3.2 & 11.1 & 13.9 & 5.6 \\
\hline $\mathrm{F}$ & 3.61 & 13.68 & 1.8 & 2.65 & 8.26 & 1.69 & 0.74 & 1.98 & 0.55 \\
\hline$P>F$ & 0.05 & 0.01 & ns & ns & $<0.01$ & ns & ns & ns & ns \\
\hline
\end{tabular}

Grain weight is a mean value calculated from a random sample of 500 grains. ns $=$ non significant.

$\mathrm{CV}$ : coefficient of variation. F: ratio of treatments mean square and experimental error mean square.

in 2000, particularly in Lumaco, which probably caused the lower mean grain yield there in 2001, as compared with 2000 and 2002 (Table 2). The effect of increasing P fertilization rates on grain yield in Lumaco in 2001 fitted a linear model response and a quadratic model response for Selva Oscura with Equations [3] and [4], respectively:

$y=1129.10476+10.23309 \mathrm{P}$, with $\mathrm{R}^{2}=0.63$

$y=1890.05955+15.48615 \mathrm{P}-0.06904 \mathrm{P}^{2}$,

with $\mathrm{R}^{2}=0.54$

where $y, \mathrm{P}$, and $\mathrm{R}^{2}$ are described Equations [1] and [2].

There was no significant effect of $\mathrm{P}$ fertilization on grain yield at any site. Unlike previous years, liming was applied in 2002 due to the high percentage of $\mathrm{Al}$ saturation found at both sites (Table 1). As a result, plant growth at both sites was more vigorous during 2002 than in previous years. Although not the aim of the present experiment, development of the grass pea plant was found to be severely limited by medium to high $\mathrm{Al}$ saturation and its associated high soil acidity. As a consequence, corrective liming was very effective. In addition, rainfall in October-December 2002 was unusually high (Figure 1) and soil moisture was still abundant during the favorable temperatures of late spring. These conditions may have enhanced $\mathrm{P}$ mineralization from organic soil fraction. Thus, the lack of response to added P during 2002 may have resulted from more available $\mathrm{P}$ in the soil. This would explain the very high grain yields (3248 and $2796 \mathrm{~kg} \mathrm{ha}^{-1}$ in Lumaco and Selva Oscura, respectively) achieved by controls where $\mathrm{P}$ was not applied.

Phosphate fertilization did not have a significant effect on grain weight in any site or year despite the relatively
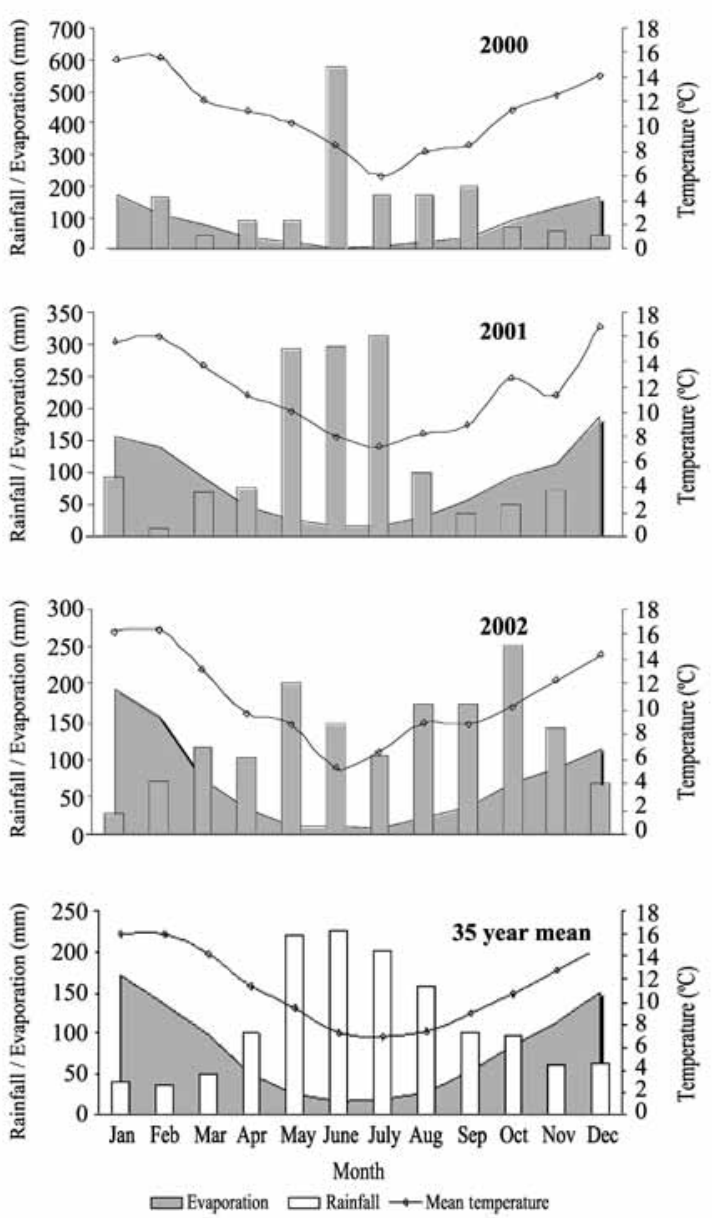

Figure 1. Monthly rainfall, evaporation, and mean temperature during 2000, 2001, 2002, and 35-yr mean at Carillanca, La Araucanía Region, southern Chile. 
Table 4. Nutrient content of aboveground biomass of grass pea cv. Luanco-INIA during flowering stage in Lumaco, southern Chile in $\mathbf{2 0 0 0 - 2 0 0 1}$ for six rates of $P$ fertilization.

\begin{tabular}{|c|c|c|c|c|c|c|c|c|c|}
\hline Applied phosphorus & $\mathbf{N}$ & $\mathbf{P}$ & $\mathbf{K}$ & $\mathrm{Ca}$ & Mg & Zn & Mn & $\mathrm{Cu}$ & $\mathbf{B}$ \\
\hline \multicolumn{10}{|l|}{$\mathrm{kg} \mathrm{ha}^{-1} \mathrm{P}$} \\
\hline 0.0 & 2.18 & 0.13 & 0.54 & 0.51 & 0.27 & 13.0 & 67.0 & 5.0 & 31.0 \\
\hline 21.8 & 1.83 & 0.10 & 0.51 & 0.48 & 0.26 & 12.0 & 65.0 & 5.0 & 32.0 \\
\hline 43.6 & 2.31 & 0.09 & 0.53 & 0.62 & 0.25 & 12.0 & 83.0 & 4.0 & 34.0 \\
\hline 65.4 & 2.17 & 0.09 & 0.51 & 0.53 & 0.25 & 12.0 & 74.0 & 4.0 & 31.0 \\
\hline 87.2 & 1.98 & 0.10 & 0.46 & 0.58 & 0.30 & 14.0 & 73.0 & 4.0 & 35.0 \\
\hline 109.0 & 2.18 & 0.11 & 0.47 & 0.56 & 0.27 & 13.0 & 67.0 & 4.0 & 32.0 \\
\hline Mean & 2.11 & 0.10 & 0.50 & 0.55 & 0.27 & 12.7 & 71.5 & 4.3 & 32.5 \\
\hline
\end{tabular}

Data are from a compound sample of three replicates.

Table 5. Nutrient accumulation by aboveground biomass of grass pea cv. Luanco-INIA up to flowering stage in Lumaco, southern Chile in 2000-2001 for six rates of $P$ fertilization.

\begin{tabular}{|c|c|c|c|c|c|c|c|c|c|}
\hline Applied phosphorus & $\mathbf{N}$ & $\mathbf{P}$ & $\mathbf{K}$ & Ca & Mg & Zn & Mn & $\mathrm{Cu}$ & B \\
\hline $\mathrm{kg} \mathrm{ha}^{-1} \mathrm{P}$ & & & $\mathrm{m}^{-2}$ & & 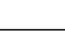 & 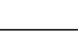 & $\mathrm{m}$ & & \\
\hline 0.0 & 14.9 & 0.89 & 3.7 & 3.5 & 1.8 & 8.9 & 45.6 & 3.4 & 21.1 \\
\hline 21.8 & 17.0 & 0.93 & 4.7 & 4.5 & 2.4 & 11.1 & 60.3 & 4.6 & 29.7 \\
\hline 43.6 & 22.7 & 0.88 & 5.2 & 6.1 & 2.5 & 11.8 & 81.4 & 3.9 & 33.4 \\
\hline 65.4 & 20.3 & 0.84 & 4.8 & 5.0 & 2.3 & 11.2 & 69.3 & 3.7 & 29.0 \\
\hline 87.2 & 25.6 & 1.30 & 6.0 & 7.5 & 3.9 & 18.1 & 94.5 & 5.2 & 45.3 \\
\hline 109.0 & 23.5 & 1.20 & 5.1 & 6.0 & 2.9 & 14.0 & 72.3 & 4.3 & 34.5 \\
\hline Mean & 20.7 & 1.00 & 4.9 & 5.4 & 2.6 & 12.5 & 70.6 & 4.2 & 32.2 \\
\hline
\end{tabular}

Nutrient accumulation was calculated by multiplying nutrient content by aboveground biomass.

low coefficients of variation for this trait. The 3-yr mean grain weight was higher in Selva Oscura (342 mg) than in Lumaco (305 mg), due to the relatively higher water availability during the pod filling stage in Selva Oscura. Variations in grain yield were not related to mean grain weight nor associated to the number of grains per pod, which had a mean of $\sim 1.6$. The number of pods per plant was the yield component that largely explained variations in grain yield. In 2000, plots that yielded 900-1600 kg ha $^{-1}$ had 6-12 pods per plant, whereas those yielding 2300$3300 \mathrm{~kg} \mathrm{ha}^{-1}$ had 13-24 pods per plant (data not shown). This noticeable difference was observed in plots with similar stands of 38-40 plants $\mathrm{m}^{-2}$.

Phosphate fertilization did not affect aboveground biomass in 2000, but did in 2002. In Lumaco and Selva Oscura, dry matter at flowering increased from $2919 \mathrm{~kg}$ ha $^{-1}$ in controls where $\mathrm{P}$ was not applied to $7483 \mathrm{~kg} \mathrm{ha}^{-1}$ with $109 \mathrm{~kg} \mathrm{P} \mathrm{ha}^{-1}$ and 3489 to $5560 \mathrm{~kg} \mathrm{ha}^{-1}$, respectively (data not shown). Plant height increased at least $10 \mathrm{~cm}$ as a result of $\mathrm{P}$ fertilization. Controls with no $\mathrm{P}$ were $47 \mathrm{~cm}$ tall during full flowering, whereas plots receiving P measured $57-63 \mathrm{~cm}$ with no significant differences between $P$ rates.
The chemical characterization of the aboveground biomass during grass pea flowering in Lumaco in 2000 is shown in Table 4. Phosphate fertilization did not apparently affect neither $\mathrm{N}$ content, which was relatively high nor $\mathrm{P}$, $\mathrm{K}, \mathrm{Ca}, \mathrm{Mg}$, and micronutrients. Nutrient absorption by the aboveground biomass up to the flowering stage in Lumaco is presented in Table 5. In general, macro and micronutrients appeared to be absorbed to a greater extent with higher rates of $\mathrm{P}$ fertilization.

Nutrient content in the grass pea grain from both sites was unaffected by $\mathrm{P}$ treatments in 2000 (Table 6). However, mean $\mathrm{N}$ content of grain from Selva Oscura was less than that from Lumaco, probably due to limitations on symbiotic $\mathrm{N}$ fixation from high soil acidity associated with the above-mentioned $\mathrm{Al}$ saturation condition. On the contrary, $\mathrm{P}, \mathrm{K}, \mathrm{Zn}$, and $\mathrm{Cu}$ were notably greater in grain from Selva Oscura than from Lumaco, and this was true to a lesser extent for $\mathrm{Ca}, \mathrm{Mg}, \mathrm{Mn}$, and $\mathrm{B}$. In general, nutrient absorption by grass pea grain was higher with increased $\mathrm{P}$ fertilization (Table 7), due to the better yield associated with it. Absorption means were lower in Selva Oscura because of lower yields. 
Table 6. Nutrient content of grass pea grain cv. Luanco-INIA in Lumaco and Selva Oscura, southern Chile in $2000-2001$ for six rates of $P$ fertilization.

\begin{tabular}{|c|c|c|c|c|c|c|c|c|c|}
\hline Applied phosphorus & $\mathbf{N}$ & $\mathbf{P}$ & $\mathbf{K}$ & $\mathbf{C a}$ & Mg & Zn & Mn & $\mathbf{C u}$ & $\mathbf{B}$ \\
\hline $\mathrm{kg} \mathrm{ha}^{-1} \mathrm{P}$ & & 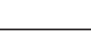 & $\%$ & & & 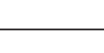 & $-\mathrm{m \xi}$ & & \\
\hline \multicolumn{10}{|l|}{ Lumaco } \\
\hline 0.0 & 4.0 & 0.23 & 0.67 & 0.10 & 0.09 & 23 & 22 & 5 & 6 \\
\hline 21.8 & 4.2 & 0.28 & 0.73 & 0.10 & 0.09 & 24 & 19 & 5 & 8 \\
\hline 43.6 & 3.9 & 0.20 & 0.67 & 0.11 & 0.09 & 19 & 22 & 5 & 8 \\
\hline 65.4 & 4.5 & 0.20 & 0.69 & 0.10 & 0.08 & 21 & 22 & 5 & 9 \\
\hline 87.2 & 4.0 & 0.23 & 0.65 & 0.10 & 0.09 & 24 & 21 & 5 & 8 \\
\hline 109.0 & 4.2 & 0.18 & 0.67 & 0.11 & 0.09 & 20 & 23 & 5 & 8 \\
\hline Mean & 4.1 & 0.22 & 0.68 & 0.10 & 0.09 & 21.8 & 21.5 & 5.0 & 7.8 \\
\hline \multicolumn{10}{|l|}{ Selva Oscura } \\
\hline 0.0 & 3.6 & 0.37 & 0.90 & 0.13 & 0.11 & 32 & 24 & 8 & 10 \\
\hline 21.8 & 3.6 & 0.37 & 0.90 & 0.12 & 0.11 & 31 & 23 & 7 & 8 \\
\hline 43.6 & 3.3 & 0.36 & 0.91 & 0.12 & 0.11 & 30 & 24 & 8 & 9 \\
\hline 65.4 & 3.6 & 0.37 & 0.91 & 0.11 & 0.11 & 30 & 24 & 7 & 9 \\
\hline 87.2 & 3.8 & 0.34 & 0.91 & 0.12 & 0.11 & 30 & 22 & 7 & 11 \\
\hline 109.0 & 3.8 & 0.36 & 0.90 & 0.11 & 0.11 & 30 & 25 & 7 & 10 \\
\hline Mean & 3.6 & 0.36 & 0.91 & 0.12 & 0.11 & 30.5 & 23.7 & 7.3 & 9.5 \\
\hline
\end{tabular}

Data are from a compound sample of three (Lumaco) and four (Selva Oscura) replicates.

Table 7. Nutrient accumulation by grass pea grain cv. Luanco-INIA in Lumaco and Selva Oscura, southern Chile, 20002001, for six rates of $\mathbf{P}$ fertilization.

\begin{tabular}{|c|c|c|c|c|c|c|c|c|c|}
\hline Applied phosphorus & $\mathbf{N}$ & $\mathbf{P}$ & $\mathbf{K}$ & Ca & Mg & Zn & Mn & $\mathbf{C u}$ & B \\
\hline $\mathrm{kg} \mathrm{ha}^{-1} \mathrm{P}$ & 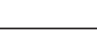 & 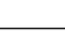 & $\mathrm{kg} \mathrm{ha}^{-1}$ & & & & - g & & \\
\hline \multicolumn{10}{|l|}{ Lumaco } \\
\hline 0.0 & 81 & 4.7 & 13.6 & 2.0 & 1.8 & 47 & 45 & 10 & 12 \\
\hline 21.8 & 97 & 6.5 & 16.9 & 2.3 & 2.1 & 56 & 44 & 12 & 19 \\
\hline 43.6 & 95 & 4.9 & 16.4 & 2.7 & 2.2 & 46 & 54 & 12 & 20 \\
\hline 65.4 & 122 & 5.4 & 18.7 & 2.7 & 2.2 & 57 & 60 & 14 & 24 \\
\hline 87.2 & 113 & 6.5 & 18.3 & 2.8 & 2.5 & 68 & 59 & 14 & 23 \\
\hline 109.0 & 113 & 4.8 & 17.9 & 2.9 & 2.4 & 54 & 62 & 13 & 21 \\
\hline Mean & 103.5 & 5.5 & 17.0 & 2.6 & 2.2 & 54.7 & 54.0 & 12.5 & 19.8 \\
\hline \multicolumn{10}{|l|}{ Selva Oscura } \\
\hline 0.0 & 27 & 2.8 & 6.7 & 1.0 & 0.8 & 24 & 18 & 6 & 8 \\
\hline 21.8 & 33 & 3.4 & 8.2 & 1.1 & 1.0 & 29 & 21 & 6 & 7 \\
\hline 43.6 & 34 & 3.7 & 9.4 & 1.2 & 1.1 & 31 & 25 & 8 & 9 \\
\hline 65.4 & 42 & 4.3 & 10.5 & 1.3 & 1.3 & 35 & 28 & 8 & 10 \\
\hline 87.2 & 50 & 4.4 & 11.9 & 1.6 & 1.4 & 39 & 29 & 9 & 14 \\
\hline 109.0 & 53 & 5.0 & 12.5 & 1.5 & 1.5 & 42 & 35 & 10 & 14 \\
\hline Mean & 39.8 & 3.9 & 9.9 & 1.3 & 1.2 & 33.3 & 26.0 & 7.8 & 10.3 \\
\hline
\end{tabular}

Nutrient accumulation was calculated by multiplying nutrient content by grain yield. 


\section{CONCLUSIONS}

Phosphate fertilization was associated with higher grass pea yields in soils with low $\mathrm{P}$ availability and retention capacity. The grain yield potential of grass pea in southern Chile was confirmed to be quite high, although grain yield was linked to the amount of rainfall during the cropping season. In a dryland area, high rainfall in spring may decrease the effect of $\mathrm{P}$ fertilization on grain yield. With a limited water supply, a growing condition that is frequent for this crop, grass pea crops should respond to $\mathrm{P}$ fertilization in soils with available P-Olsen $\leq 10 \mathrm{mg} \mathrm{kg}^{-1}$.

\section{ACKNOWLEDGEMENTS}

Research funded through FNDR Project BIP 20155696-0, granted by Gobierno Regional de La Araucanía, Chile. We are grateful to Colin Hanbury, Department of Agriculture and Food, W. Australia, and Jairo Palta, CSIRO Plant Industry, W. Australia, for help in improving the manuscript. Thanks are also due to Nelba Gaete and Héctor Pauchard, INIA-Carillanca, for providing climatic data and technical assistance.

\section{RESUMEN}

La fertilización fosfatada puede incrementar el rendimiento de cultivos productivos de chícharo (Lathyrus sativus L.) en suelos con retención de fósforo. La información sobre el requerimiento de fósforo de cultivos de chícharo (Lathyrus sativus L.) es muy escasa, particularmente en suelos que retienen este elemento. En consecuencia, se evaluó el efecto de la fertilización fosfatada sobre el rendimiento y peso del grano de chícharo (variedad Luanco-INIA) en suelos con baja disponibilidad de $\mathrm{P}$ y alta capacidad de retención de $\mathrm{P}$, en campos de pequeños agricultores de la Región de La Araucanía, sur de Chile (37³0'-39³0'S). Los ensayos se realizaron durante 2000-2001, 2001-2002 y 2002-2003 en seis sitios; tres en el área de Lumaco y tres en el área de Selva Oscura. Se evaluaron seis dosis de $\mathrm{P}(0 ; 21,8 ; 43,6 ; 65,4 ; 87,2$ y 109,0 $\mathrm{kg} \mathrm{ha}^{-1}$ ) en un diseño de bloques completos al azar con cuatro repeticiones. Se sembró a razón de 47 semillas $\mathrm{m}^{-2}$. El rendimiento de grano de todos los ensayos promedió $2456 \mathrm{~kg} \mathrm{ha}^{-1}$. La fertilización fosfatada incrementó el rendimiento de grano del chícharo durante las temporadas agrícolas 2000-2001 y 2001-2002, en ambas áreas. No hubo efecto significativo en 2002-2003, temporada de cultivo con una caída pluviométrica inusualmente elevada en primavera-verano, lo cual podría haber aumentado la tasa de mineralización de $\mathrm{P}$ desde la fracción orgánica del suelo y en consecuencia la disponibilidad de P. Asimismo, es posible que el crecimiento del sistema radical haya sido favorecido y con ello la exploración de un mayor volumen de suelo. De acuerdo a este estudio, cultivos de chícharo de esta variedad, en suelos con menos de $10 \mathrm{mg} \mathrm{kg}^{-1}$ de P-Olsen disponible, deberían responder a la fertilización fosfatada.

Palabras clave: almorta, Lathyrus, fósforo, cultivos desatendidos, leguminosas de grano de estación templada fría.

\section{LITERATURE CITED}

Besoaín, E., y A. Sadzawka. 1999. Fenómenos de retención de fósforo en los suelos volcánicos y sus consecuencias. p. 27-36. In Besoaín, E., C. Rojas, y A. Montenegro (eds.) Las rocas fosfóricas y sus posibilidades de uso agrícola en Chile. Instituto de Investigaciones Agropecuarias, Santiago, Chile.

Campbell, C.G. 1997. Grass pea. Lathyrus sativus L. Promoting the conservation and use of underutilized and neglected crops. Vol. 18. 92 p. Institute of Plant Genetics and Crop Plant Research, Gatersleben, Germany/International Plant Genetic Resources Institute, Rome, Italy.

Campbell, C.G., R.B. Mehra, S.K. Agrawal, Y.Z. Chen, A.M. Abd El Moneim, H.I.T. Khawaja, et al. 1994. Current status and future strategy in breeding grass pea (Lathyrus sativus). Euphytica 73:167-175.

Casanova, M., W. Vera, y W. Luzio. 2006. Rasgos morfológicos de los suelos. p. 43-90. In Luzio, W., y M. Casanova (eds.) Avances en el conocimiento de los suelos de Chile. Universidad de Chile, Santiago, Chile.

CIREN. 2002. Descripciones de suelos, materiales y símbolos. Estudio agrológico IX Región. Publicación $N^{\circ}$ 122. 360 p. Centro de Información de Recursos Naturales (CIREN), Santiago, Chile.

CIREN. 2003. Descripciones de suelos, materiales y símbolos. Estudio agrológico X Región. Tomo II. Publicación No 123. 412 p. Centro de Información de Recursos Naturales (CIREN), Santiago, Chile.

Ellena, M. 1983. Efecto del distanciamiento entre hileras y diferentes fórmulas de fertilización sobre los rendimientos y sus componentes en chícharos (Lathyrus sativus L.). Tesis Ingeniero Agrónomo. Universidad Austral de Chile, Facultad de Ciencias Agrarias, Valdivia, Chile.

Hanbury, C.D., C.L. White, B.P. Mullan, and K.H.M. Siddique. 2000. A review of the potential of Lathyrus sativus $\mathrm{L}$. and $L$. cicera $\mathrm{L}$. grain for use as animal feed. Anim. Feed Sci. Technol. 87:1-27. 
Krarup, A. 2002. Blanco Austral, cultivar de chícharo (Lathyrus sativus L.) obtenido por selección del rendimiento por planta y de sus componentes. Agrosur 30:40-46.

Lambein, F., Y.H. Kuo, K. Kusama-Eguchi, and F.I. Ikegami. 2007. 3-N-Oxalyl-L-2,3-diaminopropanoic acid, a multifunctional plant metabolite of toxic reputation. Arkivoc 2007(9):45-52.

Mera, M., J. Tay, A. France, A. Montenegro, N. Espinoza, N. Gaete, and L. Barrientos. 2003. Luanco-INIA, a large-seeded cultivar of Lathyrus sativus released in Chile. Lathyrus Lathyrism Newsletter 3:26.

Montenegro, A. 1991. Diagnóstico preliminar de los tenores de nitrógeno, fósforo, potasio, materia orgánica y pH de los suelos de la IX Región. Investigación y Progreso Agropecuario Carillanca 10(3):3-11.

Montenegro, A., E. Besoaín, y C. Toro. 1999b. Aplicación directa de rocas fosfóricas y mezclas de rocas con fertilizantes fosfatados solubles en el cultivo del raps, en Andisoles de la IX Región. p. 255-270. In Besoaín, E., C. Rojas, y A. Montenegro (eds.) Las rocas fosfóricas y sus posibilidades de uso agrícola en Chile. Instituto de Investigaciones Agropecuarias, Santiago, Chile.

Montenegro, A., E. Besoaín, C. Toro, y E. Contreras. 1999a. Evaluación agronómica del uso de rocas fosfóricas en la fertilización fosfatada del trigo, en suelos derivados de cenizas volcánicas de la IX Región. p. 217-241. In Besoaín, E., C. Rojas, y A. Montenegro (eds.) Las rocas fosfóricas y sus posibilidades de uso agrícola en Chile. Instituto de Investigaciones Agropecuarias, Santiago, Chile.

Montenegro, A., M. Mera, N. Espinoza, L. Barrientos, and N. Gaete. 2001. Effect of phosphate fertilization on Lathyrus sativus in soils with high phosphorus retention capacity. Lathyrus Lathyrism Newsletter 2:95-98.
Pino, I., W. Luzio, y A.M. Parada. 1998. Cinética de intercambio isotópico en suelos derivados de cenizas volcánicas. Un modelo predictivo. Agric. Téc. (Chile) 58:56-64.

Sadzawka, A., R. Campillo, A. Montenegro, y C. Rojas. 1999. Determinación de la capacidad tampón de fósforo en suelos ácidos. p. 49. In Salazar, I. (ed.) Proceedings $14^{\circ}$ Congreso Latinoamericano de la Ciencia del Suelo, Pucón, Chile. 8-12 noviembre 1999. Universidad de La Frontera, Temuco, Chile.

Sadzawka, A., M. Carrasco, R. Grez, M.L. Mora, H. Flores, y A. Neaman. 2006. Métodos de análisis recomendados para los suelos de Chile. Revisión 2006. Serie Actas INIA No 34.164 p. Instituto de Investigaciones Agropecuarias, Santiago, Chile.

Sadzawka, A., M. Carrasco, R. Demanet, H. Flores, R. Grez, M.L. Mora, y A. Neaman. 2007. Métodos de análisis de tejidos vegetales. $2^{\mathrm{a}}$ ed. Serie Actas INIA ${ }^{\circ}$ 40. 140 p. Instituto de Investigaciones Agropecuarias, Santiago, Chile.

Sarkar, R.K., B. Biswas, and G.C. Malik. 2003. Productivity of grass pea (Lathyrus sativus L.) under different levels of phosphorus and foliar spray of molybdenum. Lathyrus Lathyrism Newsletter 3:3637.

SAS Institute. 1992. STAT@ User's guide for personal computers. 704 p. 8th ed. SAS Institute, Cary, North Carolina, USA.

Siddique, K.H.M., C.L. Hanbury, and A. Sarker. 2006. Registration of 'Ceora' grass pea. Crop Sci. 46:986.

Siddique, K.H.M., S.P. Loss, S.P. Herwig, and J.M. Wilson. 1996. Growth, yield and neurotoxin (ODAP) concentration of three Lathyrus species in Mediterranean-type environments of Western Australia. Aust. J. Exp. Agric. 36:209-218. 